\title{
Replies
}

\section{Revision and Apology in Antitrust Federalism}

\author{
John Shepard Wiley Jr.†
}

In this Journal, Merrick B. Garland recently criticized my article, $A$ Capture Theory of Antitrust Federalism. ${ }^{1}$ I based my argument there on the familiar notion that businesses, for their own anticompetitive profit, can capture the governmental bodies and policies that supposedly regulate them in the public interest. I claim that this "capture theory" illuminates past Supreme Court decisions concerning "antitrust federalism": the issue of which state and local laws are preempted by the federal Sherman Act. I further suggest that federal judges could overcome flaws in current doctrine by incorporating the notion of capture into future decisions. $\mathrm{Mr}$. Garland responds that I am a revisionist, and a dangerous one at that. $\mathrm{He}$ defends current doctrine, and asserts that a capture theory inaccurately describes case law, improperly adopts economic efficiency as a preemptive federal goal, and leads to dangerous problems. Mr. Garland's analysis is thoughtful and scholarly. But I hope to convince readers that my argument survives his apology for current doctrine.

\section{Descriptively INACCURATE?}

Mr. Garland devotes the bulk of his effort to attacking the descriptive power of a capture approach, and I therefore concentrate my comments on this topic. Mr. Garland argues that a capture theory fails to describe the

$\dagger$ Acting Professor of Law, UCLA School of Law. I thank Rob Boyd, Harold Demsetz, Jim Liebeler, Stan Ornstein, Mark Ramseyer, Eric Rasmussen, Ken Taymor, Mike Waldman, and Eric Zolt for helpful conversations about New York's system of liquor regulation and, inevitably, Steve Yeazell for a variety of insightful comments.

1. Garland, Antitrust and State Action: Economic Efficiency and the Political Process, 96 Yale L.J. 486 (1986) (criticizing Wiley, A Capture Theory of Antitrust Federalism, 99 HARv. L. REv. 713 (1986)). 
decisions since the seminal case of Parker v. Brown precisely. ${ }^{2}$ I could not agree more. No sensible theory does. That is the problem.

I argue that Parker built its state action doctrine upon deference to states; that a significant number ${ }^{3}$ of decisions since Parker have interfered with state regulatory autonomy; and that this interference is consistent with a change in intellectual climate from ready acceptance to marked suspicion of the benefits of regulation. I conclude that this growing suspicion of regulation has created a tension in antitrust federalism doctrine that was absent in Parker. ${ }^{4}$ This tension makes understandable, although it certainly does not reconcile, the substantial disarray within the postParker case law. ${ }^{\mathbf{5}}$

Mr. Garland claims that he has a better account of the cases since Parker. He argues that the Court has been balancing respect for state and national political processes. In his view, the Court distinguishes between exempt "public" and reviewable "private" restraints by assessing a given policy's degree of delegation to private decisionmaking. Mr. Garland acknowledges that I present just this characterization as the stated tendency of doctrine since the Midcal case. ${ }^{6} \mathrm{He}$ and I differ only in our satisfaction with this level of analysis. Mr. Garland likes and defends it; I criticize and reject it. I find this account of recent antitrust federalism so unresponsive to both antitrust and federalism concerns as to be symptomatic of a deeper and largely unarticulated clash of values-a clash that I seek to identify and describe.?

Mr. Garland states that decisions since Parker have sought to "reconcile the Court's respect for the political process in the states with its respect for the national political process." federalism problem is not very helpful. To respect state political processes means to uphold local laws against federal attack. To respect the national political process means to enforce federal laws. The Court can do both only in the easy cases where local and federal policies do not really conflict. Cases in which there really is conflict are also easy, because the

2. 317 U.S. 341 (1943); Garland, supra note 1, at 489-518.

3. I say eight; Mr. Garland says six. Garland, supra note 1, at 492 n.34. Mr. Garland excludes Flood v. Kuhn, 407 U.S. 258 (1972), and Maryland v. United States, 460 U.S. 1001 (1983), because those decisions spend little or no time discussing Parker. I agree that neither decision dwells on the state action issue, Wiley, supra note 1, at 720, 722. However, Mr. Garland does not dispute my point that neither result would have been possible had the Court accepted a state action defense.

4. See Wiley, supra note 1 , at 715 .

5. See id. at $722-23,736-39$.

6. California Retail Liquor Dealers Ass'n v. Midcal Aluminum, Inc., 445 U.S. 97 (1980); see Garland, supra note 1, at 501 \& n.86 (citing my delegation analysis with approval).

7. See Wiley, supra note 1, at 723 ("These cases suggest that something has been challenging Parker's premise of deference to state regulatory policy, though their language gives little clue about what that thing is.").

8. Garland, supra note 1 , at 499. 
supremacy clause dictates that federal law always wins in real showdowns. Saying that courts "reconcile" respect for both local and federal laws declares that courts do either the obvious or the impossible. This description does not take us far.

Mr. Garland also says that the Court has sought to separate "true state regulation" from "mere state 'authorization' of private conduct." This description is also unhelpful. Mr. Garland's faith in the naturalness of any one criterion for distinguishing between public and private action is vulnerable to the decades of scholarship that have exploded the idea that some natural line divides public from private action. ${ }^{10}$ The choice of any particular criterion for labelling an act as "true" state action rather than "mere" private action reflects-and must be defended in terms of-pursuit of some value." Saying that the Court is dividing public from private action restates the question but supplies no answer.

So we come to the portion of Mr. Garland's argument that is key to any convincing defense of reigning doctrine: a policy rationale for the Court's particular choice of a delegation criterion for distinguishing "true" public from "mere" private action. On this score, Mr. Garland fails.

The Court cannot have adopted an antidelegation doctrine out of regard for state autonomy, for the fact of delegation need show nothing about the authenticity of state will. Mr. Garland agrees that, for instance, the Midcal decision is good law. ${ }^{12}$ But that decision tore entire sections out of the California Business and Professions Code by airily declaring them to be "essentially ... private."13 That is not respect for states' rights. And neither the Court nor Mr. Garland demonstrates that state policies administered directly by bureaucrats are closer to the "true" hearts and minds of state citizens than are state policies that delegate considerable discretion to citizens. Californians might defend their community property laws, for example, with considerably more passion than their public utility regulations, even though-perhaps indeed because-community property laws effectuate citizens' decisions with little assistance from people on the state payroll.

By the same token, the Court cannot have adopted an antidelegation doctrine out of simple regard for federal antitrust policy. Antitrust commentators have fought long over whether populism, efficiency, or wealth

9. Id. at 501 .

10. See, e.g., Brest, State Action and Liberal Theory: A Casenote on Flagg Brothers v. Brooks, 130 U. PA. L. REv. 1296, 1302 n.21 (1982) (surveying literature).

11. Id. at 1302 .

12. Garland, supra note 1 , at 507 .

13. Midcal, 445 U.S. at 106 (1980). 
distribution are proper or decisive antitrust goals. ${ }^{14}$ But this debate has never included a goal of centralized or nondelegated state decisionmaking. If anything, the populist ideal of decentralization often found in the Sherman Act condemns this objective outright. If, alternatively, the goal of federal antitrust law is economic efficiency or just distribution of wealth, we again see no reliable correspondence between these objectives and an attack on state delegation. Analysts today commonly argue, for example, that delegated resale price maintenance of the type condemned in Midcal can in fact promote efficiency and consumer well-being. ${ }^{15}$ Hoover $v$. Ronwin $^{16}$ and Parker itself provide obvious converse examples: bureaucratically administered programs that probably offended every antitrust goal. ${ }^{17}$ From the standpoint of substantive antitrust policy, then, how a state implements its policy, rather than what its policy is, is a poor criterion for triggering intrusions on state autonomy. ${ }^{18}$ Antidelegation policy is irrational antitrust policy.

The Court's recent decision in 324 Liquor Corp. v. Duffy ${ }^{19}$ applies the doctrine that Mr. Garland defends and I criticize. In that decision, the Court unanimously ruled that section 1 of the Sherman Act preempted a New York law barring retailers from discounting liquor below a price yielding them less than a twelve percent retail profit. ${ }^{20}$ The Court's opinion contained no extensive or definitive analysis of the markup law's ac-

14. See, e.g., Wiley, supra note 1 , at 749 n.165 (summarizing literature).

15. See, e.g., Gilligan, The Competitive Effects of Resale Price Maintenanice, 17 Rand J. Econ. 546-47 (1986) (summarizing debate).

16. 466 U.S. 558 (1984).

17. Cartels are a plain antitrust evil on every score. They aggregate the scale of business decisionmaking and so affront populists, restrict supply and thereby rile efficiency proponents, and enable producers to appropriate surplus and thus offend distributivists. Parker involved state agricultural regulation that apparently created a raisin cartel. While some will doubt Mr. Ronwin's claim that the officially administered Arizona bar exam was a cartel entry barrier, his case's procedural posture forced the Court to accept this possibility for purposes of its decision. Hoover, 466 U.S. at 565-66.

18. Nor does antidelegation policy promote procedures that serve federal antitrust interests. Suppose we fear that a state legislature may adopt policies that offend substantive federal interests: policies that are anticompetitive, anticonsumer, and inefficient. I have argued that we have no dependable reason to believe that the procedural hoops that Midcal requires will protect federal interests. See Wiley, supra note 1 , at 731-33 \& nn.92 \& 93. Mr. Garland expresses no disagreement.

19. 107 S. Ct. 720 (1987).

20. Justice O'Connor, joined by Chief Justice Rehnquist, disagreed with the majority's conclusion that the Twenty-First Amendment offered no protection for the state law at issue, but no Justice dissented from the majority's Sherman Act analysis. See 107 S. Ct. at 730-34.

The mandatory markup regulation set liquor price foors by directing wholesalers to "post" (that is, file with the State Liquor Authority (SLA)) a "bottle price" that applied to all New York liquor retailers. See N.Y. Alco. BEv. CoNT. Law $\S \S 101-b 3(b), 101-b 2,101-b b 2(b)$ (McKinney 1970). But bottle price did not necessarily represent the real "case price" at which transactions between wholesalers and retailers in fact occurred; a state regulation gave wholesalers the option of discounting case prices to retailers without lowering the bottle price filed with the SLA. See SLA Bulletin 471, quoted in $107 \mathrm{~S}$. Ct. at 723 n.4. The regulation thus guaranteed retailers a minimum twelve percent profit, which grew larger as wholesalers discounted real "case prices" below the posted "bottle prices" that set the price floor to retailers' customers. 
tual anticompetitive effect. Rather it mentioned a variety of possibilities and finally asserted that "the purpose of the 12 percent minimum markup is to protect small retailers."

The Court had reason to believe that the markup law had some anticonsumer effect. According to a number of explanations, resale price maintenance policies can promote efficiency and consumer welfare, but economists have questioned the applicability of these explanations to the liquor industry. ${ }^{22} \mathrm{~A}$ different explanation for resale price maintenance posits a retailers' cartel. ${ }^{23}$ While the New York law apparently gave liquor dealers less than a complete and simple cartel, ${ }_{2}^{24}$ the law's legislative history suggests a variation on the same theme: a ban on the selectively aggressive pricing or "loss leaders" about which losing retailers had complained to the legislature. ${ }^{25}$ As a prima facie matter at least, the Court thus was entitled to assume that the regulation aimed to restrain retailer competition (although perhaps only one type of aggressive promotional pricing) for the benefit of less efficient liquor stores.

21. $107 \mathrm{~S}$. Ct. at 728. The opinion mentioned four apparently different and potentially contradictory theories about the law's effect: (1) facilitation of horizontal collusion among manufacturers; (2) facilitation of horizontal collusion among wholesalers; (3) establishment of a horizontal price floor for the benefit of retailers; and (4) strengthening the vertical control of distillers over wholesalers. $107 \mathrm{~S}$. Ct. at 724. The Court did not offer analysis or data to support one theory over the others.

22. See Ornstein \& Hanssens, Resale Price Maintenance: Output Increasing or Restricting? The Case of Distilled Spirits in the United States, 35 J. Indus. EcoN. (forthcoming 1987); $c f$. Fenili \& Lane, Thou Shalt Not Cut Prices!, Reg., Sept.-Oct. 1985, at 31, 33-35 ("general [sales below cost] laws cost consumers more than $\$ 6.7$ billion in 1982); Smith, An Analysis of State Regulations Governing Liquor Store Licensees, 25 J.L. \& Econ. 301,319 (1982) (generally ascribing liquor regulations to political capture rather than pursuit of economic efficiency).

23. See, e.g., Gilligan, supra note 15 , at 545-46. Still a different account portrays resale price maintenance as the tool of a manufacturers' or wholesalers' cartel. See Telser, Why Should Manufacturers Want Fair Trade?, 3 J.L. \& EcoN. 86, 96-99 (1960). The New York markup law possibly facilitated such supplier cartelization. By requiring suppliers who sell to retailers to disclose their case as well as bottle prices publicly, $\S 101-\mathrm{b} 3(\mathrm{~b})$ of the New York law reduced the destabilizing threat of secret discounting by suppliers to retailers. But suppliers' cartels ought to oppose the policy of SLA Bulletin 471 , quoted in $107 \mathrm{~S}$. Ct. at $723 \mathrm{n} .4$, permitting suppliers to discount case prices without reducing bottle prices. See supra note 20 . This policy seems to enable suppliers to increase retailers' margins-an undesirable result from the perspective of a selfish manufacturer or wholesaler cartel trying to appropriate the entire monopoly profit. This "upstream cartel" explanation thus accounts only imperfectly for the details of the New York law.

24. The nominal $12 \%$ margin hardly seems a monopoly margin and may be significant only when compared to single-digit markups in highly efficient retail stores like supermarkets-a comparison that might be unrealistic for the retail liquor industry. The Court did cite evidence that wholesalers sometimes advertised case discounts that would yield retail markups in excess of $30 \%$. $107 \mathrm{~S}$. Ct. at 723. But the Court offered neither theoretical explanation why wholesalers would do so nor systematic data confirming that this practice had been more than sporadic.

25. In a triumph of euphemism over competition, the legislative history of New York's 1971 law reported that "competitive excesses" plagued New York liquor retailing. N.Y. LeGisLature, Senate Excise Comm., Final. Report 22 (Mar. 5, 1971) [hereinafter Final RePort]. After describing the evils of "loss leaders," the report condemned existing New York regulation for permitting pricing, "unduly geared to consumer prices, that [did] not realistically provide for the continuance of the retail level of [the liquor] industry. This failure would appear to represent a substantial economic dislocation that might be deemed disruptive of the economy of an entire industry." Id. at 25. 
This analysis of New York's law puts it squarely at odds with substantive antitrust goals. The Sherman Act directs liquor retailers to compete for the benefit of consumers; New York instead enforced a degree of dealer cooperation that victimized consumers. However, the 324 Liquor Court decided that the state law was invalid not on the basis of this plain substantive conflict with federal interests, but rather because New York's system contained a procedural flaw: "New York's liquor pricing system is not actively supervised by the State." 28

This "active supervision" requirement is pointless and costly. It condemns New York's cartel effort only for involving too few hearings and bureaucrats, not for being illegitimate at its core. Consequently current doctrine permits states to pursue the same anticompetitive end as long as they incorporate the Court's directions for supervision.

Certainly New York liquor retailers could demand that the state legislature ornament their substantive anticompetitive concern with new regulatory processes. ${ }^{27}$ But encouraging a more cumbersome regulatory maze lacks federal purpose. Intricacy need alter not one whit New York's regulatory objective of restricting retail competition for the benefit of inefficient firms. Nor will throwing more bureaucrats at the problem make some revised regulatory structure a metaphysically "truer" expression of authentic state will. Moreover, 324 Liquor's rule that government must regulate only clumsily can apply to and thereby hamper a great many state regulations-not just those substantively undesirable from the standpoint of antitrust goals. The Court's ruling therefore will benefit no one but New York law firms eager to enliven their administrative practice.

Because I am dissatisfied with accounts of antitrust federalism like the one 324 Liquor applies and Mr. Garland defends, I look for a more fundamental and satisfying account of recent antitrust federalism. Hence I make my claim that a new tension in the field-an increasing federal suspicion of regulation ${ }^{28}$-is the best explanation for the Court's erratic but undeniable incursions on state autonomy since Parker. ${ }^{28}$

26. $107 \mathrm{~S}$. Ct. at 725 (emphasis added). "TT]he State does not control month-to-month variations in posted prices. Nor does the State supervise the wholesaler's decision to 'post off,' . . . the corresponding decrease, if any, in the bottle price, or the frequency with which a wholesaler posts off." Id. at 726.

27. For instance, New York could require wholesalers to submit proposed prices to the SLA in advance. It could demand that the SLA examine these proposals at length. And it could order the SLA to approve only those filings that truly block retail price rivalry.

28. See Wiley, supra note 1 , at 728 .

29. I quite agree with Mr. Garland's observation that the Court has not overturned every state law that may have been a product of industry capture. Compare Garland, supra note 1, at 491 (New Motor Vehicle Bd. v. Orrin W. Fox Co., 439 U.S. 96 (1978), ignored element of capture) and Garland, supra note 1, at 491 n.32 (Hoover v. Ronwin, 466 U.S. 558 (1984), ignored element of capture) with Wiley, supra note 1 , at 746 \& $\mathrm{n} .155$ and Wiley, supra note 1 , at 739 n.131. I likewise join him in criticizing the plainly false proposition that state action cases "exhibit an inexorable trend toward 


\section{INDEFENSIBLE EFFicienCy Vogue?}

From his title to his final page, Mr. Garland criticizes my work for relying inappropriately on economic analysis. $\mathrm{He}$ also associates my work with that of prominent Chicago school analysts-most often Judge Easterbrook. This linkage arrests me and probably the Chicagoans: me, because my work does not rest upon economic efficiency as the exclusive goal of antitrust policy; the Chicagoans, because they may be disinclined to adopt me as their own!

The crucial step in any preemption case is the characterization of the federal interest. In the current context, this characterization provides the measure by which "true public" regulation is to be distinguished from "mere private" exploitation of state power. After rejecting antidelegation as a sensible expression of antitrust policy, my article sought to make its criticism constructive by offering an alternative definition of the federal antitrust interest. I settled upon efficiency, currently the most widely accepted formulation of the Sherman Act's goal. ${ }^{30}$ I noted that the antitrust case for efficiency is troubling and uncertain, but that the choice is less troubling than it might otherwise be because a general parallel exists between an efficiency approach and a just distribution approach..$^{31}$

My disclaimers did not stop my work from being compartmentalized as effectively Chicagoan. So I stress that the relevance of my proposal is not restricted to Ghicago believers. My analysis need not be founded exclusively upon a goal of efficiency. If we replace economic efficiency with distributive justice, my analysis remains essentially the same.

A distributive justice goal can articulate a value judgment that entitles ultimate or household consumers to the surplus they would derive from transacting in a market in which producers behave as rivals rather than as cooperators. ${ }^{32}$ This objective aims to block any effort of cooperating producers to take from consumers their competitive just deserts-the relatively low prices and abundant output that producer rivalry promotes. In the context of antitrust federalism, those unwilling to return to Parker's

\footnotetext{
greater federal intrusion." Garland, supra note 1, at 487. I further agree that the recent Fisher opinion is puzzling on its face. See Garland, supra note 1, at 503-06; Wiley, The Berkeley Rent Control Case: Treating Victims as Villains, 1986 SuP. CT. REv. 157. Finally, I agree that several recent decisions weaken the Midcal standard of review. Compare Garland, supra note 1, at 493 with Wiley, supra note 1 , at 738 . These decisions, however, purport to apply rather than overrule the precedents to which I refer supra note 3. We witness a lively doctrinal tension that needs explaining, not a "trend" or a "retreat", Garland, supra note 1, at $492,494,498$, that shows the problem is going away.

30. See Wiley, supra note 1 , at 741,751 .

31. See id. at $713,750-51$ \& n.173, 761-62 \& n.227.

32. See Lande, Wealth Transfers as the Original and Primary Concern of Antitrust: The Efficiency Interpretation Challenged, 34 Hastings L.J. 65, 74-77 (1982).
} 
absolute deference to states ${ }^{33}$ could make operational this federal distributive interest by testing state regulations in four steps: (1) Does the state or local policy restrain market rivalry? (2) Is the policy unprotected by a federal antitrust exemption? (3) Is it primarily a producer initiative, thus preliminarily suggesting that the policy is a state-backed effort to appropriate consumer wealth for producers? (4) And is the policy most likely to disadvantage consumers by impairing desirable competition without solving some serious market problem in a way beneficial to them? If the answer to each question is yes, this distributive justice standard advises a federal court to invalidate the local policy as preempted by the Sherman Act.

Consider how this analysis would work in a case like Bates $v$. State Bar..$^{34}$ The Bates Court confronted Arizona's ban on advertising for legal services. Advertising bans restrain an important aspect of producer rivalry. They do not fall within any federal exception to the Sherman Act. Moreover, the ad ban was almost certainly enacted as a result of decisive lawyer support, not as the sole or partial consequence of other interests that favored regulation of lawyers. Finally and most relevant for present purposes, the Bates Court carefully analyzed the question of whether that state ban would solve a serious market problem facing consumers. The Court's moderately intrusive review concluded that the ban was unjustified; consumers faced no likely market problems that would daunt less restrictive regulatory alternatives. That is, the ad ban was likely to harm consumers' welfare. Under this analysis, the Arizona ad ban was a lawyer-sponsored effort to disadvantage consumers of legal services to the industry's benefit rather than a regulation in consumers' interest. Under a preemptive standard of distributive justice, a federal court should invalidate the Arizona policy because federal consumer legislation-the Sherman Act-supersedes it.

The 324 Liquor decision likewise can illustrate the operation of a capture theory using the criterion of distributive justice rather than efficiency. New York's markup law satisfies the first two elements of the inquiry directly: The markup law restrained the central feature of market operation-price competition-and no relevant federal antitrust exemption for resale price maintenance has existed since the repeal of the MillerTydings and McGuire Acts. As for the third element, the history of the markup law discloses a crystal clear heritage of political capture by liquor

33. See Wiley, supra note 1 , at 740-41. Significantly, not a single Justice in the recent Fisher decision accepted Parker's premise that Congress intended that the Sherman Act leave state autonomy unimpaired. None of the three opinions in the case suggests that the Sherman Act is flatly irrelevant to public laws like initiatives.

34. 433 U.S. 350 (1977); see also Wiley, supra note 1, at 762-64 (discussing Bates). 
retailers. In 1971, the New York legislature passed the relevant statute in frank response to "inordinate and continuing emphasis on [liquor retail] price cutting and price promotions." ${ }^{\text {"35 }}$ The legislature in 1971 thus reimposed the resale price maintenance that an earlier independent state commission had resoundingly condemned as the indefensible product of industry capture. ${ }^{38}$ Considering finally the fourth element, the markup law does not help consumers combat a market problem that harms them. The state legislature had reported that the regulation was needed to forestall monopoly resulting from predatory pricing, ${ }^{37}$ but the 324 Liquor Court rightly rejected the predation argument as specious according to federal antitrust doctrine. ${ }^{38}$ The Sherman Act thus should preempt the markup rule because it hurts consumers. ${ }^{39}$

35. Final Report, supra note 25, at 35. The SLA in turn promulgated Bulletin 471 in 1973. See supra note 20.

Regulatory scandal in the early 1960's prompted Governor Rockefeller to appoint the Moreland Commission to reappraise New York's liquor regulation. After extensive study, the Commission condemned the SL $\Lambda$ 's restrictive liquor regulation as unrelated to its purported goal of promoting temperance and as "dictated by the industry, at the expense of public convenience, logic, and good administration." N.Y. State Moreland Comm'n on the Alcoholic Beverage Control. Law, Report and Recommendation No. 1, The Licensing and Regulation of Retall Package Liquor Stores 28 (Jan. 3, 1964) [hereinafter MORELAND Comm'N, Report No. 1]; see also id. at $14,15,17-18,27,36-37,39$. The Commission recommended widespread deregulation of liquor retailing. The New York legislature reacted in 1964, but only by removing a fraction of the restraints that the Commission had identified as protectionist favors for liquor retailers. Although diluted, the 1964 revisions evidently stimulated some increase in retail liquor competition. See FINAL REPORT, supra note 25 , at 35 .

36. See, e.g., Moreland Comm'n, supra note 35, Report and Recommendation No. 3, Mandatory Resal.e Price Maintenance $27-28$ (Jan. 21, 1964) ("SLA drafted this basic [resale] price control pattern under the guidance of the retail package store associations" without meeting with any "civic interest or social welfare groups, or for that matter any representative of the consuming public"); Morel.and Comm'n, supra note 35, Study Paper Number 5, Resale Price MainteNANCE IN THE LIQUOR INDUSTRY 3 (Oct. 28, 1963) ("The main beneficiaries [of NY liquor RPM] appear to have been the New York State retailers, the main victims, the New York State consumers.").

37. Final Report, supra note 25, at 29-30. See also J.A.J. Liquor Store v. N.Y. State Liquor Auth., 64 N.Y.2d 504, 520 (1985). The pretextual quality of this reasoning is evident to anyone wondering why the process has not yet produced monopolies in, for instance, hamburger or soft drink retailing.

38. That doctrine reports "a consensus among commentators that predatory pricing schemes are rarely tried, [and] even more rarely successful." Matsushita Elec. Indus. Co. v. Zenith Radio Corp., $106 \mathrm{~S}$. Ct. 1348, 1357-58 (1986). One cannot use theory to rule out predatory pricing as inevitably irrational. E.g., Milgrom \& Roberts, Predation, Reputation, and Entry Deterrence, $27 \mathrm{~J}$. EcoN. THEORY 280 (1982). But fears of predatory pricing are particularly implausible in a market as unconcentrated and easy to enter as liquor retailing. See 324 Liquor, 107 S. Ct. at 725 n.5; Cargill, Inc. v. Monfort of Colo., Inc., 107 S. Ct. 484, 494 n.15 (1986) (significant market power and high entry barriers are prerequisites to successful predatory pricing). The Moreland Commission concluded that "[t]he operation of a package store is relatively uncomplicated and requires little special skill or experience." MORELAND Comm'N, Report No. 1, supra note 35, at 8 . The only significant barriers to entering liquor retailing thus were created by the state of New York itself.

39. A markup law conceivably could serve consumer interests, but such circumstances did not exist in 324 Liquor. People preferring the existence of a small business sector for instrumental or intrinsic reasons may have difficulty expressing their views through markets. See, e.g., Hovenkamp, Antitrust Policy After Chicago, 84 Mrch. L. Rev. 213, 242-44 (1985). For instance, people might believe small shop ownership builds civic virtue or increases contributions to the Republican party or 


\section{A Danger to Free Speech and Democracy?}

Finally, Mr. Garland attacks my proposal as posing three dangers: confusion, unconstitutional abridgement of free speech, and a return to the one thing that all right-thinking lawyers reject-the hated Lochner. I demur.

\section{A. What Is "Producer Capture"?}

I argue that federal courts could use the notion of producer capture to limit their review to those state and local regulations that pose efficiency or distributive concerns. Mr. Garland explores the clarity of the concept of producer capture by posing two hypotheticals: a regulation that limits condominium conversion, and the federal air bag rule. ${ }^{40}$

The capture concept derives from Mancur Olson's insight that free riders can lead to the "'exploitation' of the great by the small."41 Producer capture occurs when a relatively concentrated industry pits its superior capacity for group action-which arises, ironically, from the relative fewness of its members-against numerous poorly organized consumers to win an anticompetitive restraint at consumers' expense. Cases that do not fit this pattern are beyond this model's limited capacity to account for the phenomenon of regulation, and so should escape further federal review. Federal judges could thus filter regulations with the concept of producer capture to distinguish regulations that deserve federal scrutiny from those that do not.

Mr. Garland's condominium hypothetical presents the "[b]ootleggers and Baptists" problem:42 a regulation like a Sunday closing law for bars and liquor stores, supported both by suppliers looking for anticompetitive protection and by others. ${ }^{43}$ Cases like this present a factual question: Was the suppliers' support for the conversion regulation decisive? A condominium regulation case where mixed support is virtually balanced defines the

is simply a good thing, period. A mandatory markup law therefore could effectuate popular and intense preferences for small business-if such preferences truly exist. Capture theory, however, urges extreme skepticism about the authenticity of such claimed popular preferences when their only expositor is the industry itself.

In 324 Liquor the stated justification for the markup regulation was its role as a tool against monopoly, not as a product of popular desire for small scale retailing per se. The 356 pages of the Moreland Commission reports, moreover, refer to "the small business ethic of our community" only once, and then only to dismiss the argument as an inadequate justification for restrictive retail regulation. See MOREland COMm'N, Report No. 1, supra note 35, at 33-35.

40. See Garland, supra note 1 , at 517.

41. M. Olson, The Logic of Collecrive Action 29 (1965) (citations omitted).

42. Yandle, Bootleggers and Baptists-The Education of a Regulatory Economist, REG., May-June 1983, at 12, 13.

43. Wiley, supra note 1 , at 770 . Condominium owners are suppliers of housing who logically could support conversion limitations as a barrier to new entry; renters are household consumers whose support would be based on other factors. 
sort of borderline case that exists for every fact-based legal rule. In factually close cases, I reiterate that the producer capture question "remains theoretically coherent, analytically tractable (particularly when combined with a suitably demanding burden of proof that plaintiffs must satisfy), and analogous to other questions that courts routinely settle."44

The air bag hypothetical also yields to Olsonian logic. Mr. Garland points out that producers, like insurance companies, can join with Ralph Nader to combat the automobile industry for an air bag rule. ${ }^{45}$ But although insurers are producers, they often "represent consumer interests." 4 When they do so, insurers act on consumers' behalf to reduce costs, rather than against consumers to appropriate monopoly or cartel profits from them. Such cases fall outside the Olsonian paradigm of industry versus consumers, and so should escape preemption under a capture theory of antitrust federalism. ${ }^{47}$

\section{B. Would a Capture Test Violate the First Amendment?}

Mr. Garland raises free speech objections to my proposed use of producer capture as a screen for signalling whether a challenged state policy warrants federal suspicion. Take for instance the Bates example. ${ }^{48}$ In that case, a capture preemption test would ask whether the organized bar-as opposed to some other set of interests-were the primary sponsor of the ban on lawyer ads. If the legal industry indeed were the main force behind the regulation, its support would create an Olsonian hint that the ban could be a selfish industry effort to bilk consumers, and that a federal court should inquire further into the regulation's justifications. If some group other than lawyers were primarily responsible for the regulation, however, the court should keep its hands entirely off the regulation because it presumably is founded upon some public interest rationale-a rationale beyond antitrust concern. The 324 Liquor case demonstrates

\footnotetext{
44. Wiley, supra note 1 , at 770 .

45. To make the air bag case an antitrust federalism rather than an antitrust exemption problem, assume that a state or local government enacted a rule requiring auto makers to offer an air bag option on new cars.

46. Arizona v. Maricopa County Medical Soc'y, 457 U.S. 332, 360 (1982) (Powell, J., dissenting); $c f$. FTC v. Indiana Fed'n of Dentists, 106 S. Ct. 2009, 2020 (1986) (insurers can represent consumer interests in dealings with other producers).

47. Mr. Garland also argues that my proposed inquiry would cause massive and unwarranted preemption of state law. He supports his conclusion by disjunctively analyzing each step of a conjunctive test. See Garland, supra note 1, at 508, 510 (laundry list of regulations "could all be overturned" by one prong of test), 516 (different prong of test "is likely to do little else than put enormous discretionary power into the hands of an unelected judiciary"). By this reasoning, critics could fault hot tea because plain water lacks flavor and dry tea sticks to the tongue. Mr. Garland does not do what his "unwarranted preemption" argument demands; he does not illustrate a single instance in which the entire test would in fact cause inappropriate preemption. Indeed, Mr. Garland's air bag hypothetical discloses that my proposal is narrower than he seems to fear.

48. See supra note 35 and accompanying text.
} 
that the concept of producer capture is clear in practical application. Mr. Garland objects, claiming that to. draw presumptive suspicion from an industry's decisive support for a challenged regulation is to "impos[e] a penalty on rights that are at the core of the First Amendment: the right to debate public issues, to petition the government, and to seek to influence the outcome of the political process."

Mr. Garland's "penalty" logic packs quite a punch. Courts routinely study the origin and legislative history of a challenged law. They seek to infer the law's true character and function from its supporters' identities and arguments. If these inferences from legislative history lead judges to negative conclusions about the law's constitutionality, then Mr. Garland would say that courts are using the supporters' political speeches and actions to help invalidate the law. Logically, then, Mr. Garland's argument expands to assert that a court violates the First Amendment whenever its historical investigation "penalizes" political actors by supporting a judicial conclusion distasteful to them.

This claim cannot be right. If the argument holds water, then the Cantor Court violated the First Amendment rights of the Detroit Edison Company by noting (to Edison's detriment) that "there can be no doubt that the option to have, or not to have, [a challenged program regulated by state law] is primarily [Edison's], not the Commission's." 50 The Washington Apple Court then violated the free speech rights of local industry when, en route to invalidating a state law as an impermissible restraint of interstate commerce, it stressed that the industry was "mainly responsible for this legislation being passed." 151 And a court would violate the speech rights of racist legislators if it used their comments in the legislative history to decide that a challenged state law was discriminatory and thus violative of equal protection. ${ }^{52}$ I do not think Mr. Garland would wish to pursue his argument this far.

49. Garland, supra note 1, at 512-13.

50. See Cantor v. Detroit Edison Co., 428 U.S. 579, 594 (1976). Mr. Garland agrees that "one can read" Cantor thus. Garland, supra note 1, at 513 n.161. He argues, however, that Cantor drew different inferences from the fact of industry involvement than did two earlier cases. Id. This does not work. The inconsistency shows only instability within antitrust federalism law (which I heartily acknowledge), not what Mr. Garland needs to get his argument off the ground, which is a later Court's free speech rejection of the error of the Cantor Court's ways. Second, Mr. Garland claims that Bates v. State Bar, 433 U.S. 350 (1977), "effectively abandoned that element of Cantor." Id. Once again, nothing Mr. Garland cites offers First Amendment support for his analysis. In short, Cantor saw no constitutional barrier to, or even issue in, drawing the inference I urge.

51. Hunt v. Washington State Apple Advertising Comm'n, 432 U.S. 333, 352 (1977). Mr. Garland does not respond to my earlier citation of this case. See Wiley, supra note 1, at 760 n.308.

52. Cf. Washington v. Davis, 426 U.S. 229 (1976) (requiring proof of discriminatory racial purpose to establish equal protection violation). 


\section{Would a Capture Test Recapitulate Lochner?}

Finally, Mr. Garland says that my proposal would commit the Lochner sin. Everyone knows that this sin is bad. We are left only with the task of defining it.

Mr. Garland seems to mean that the Lochner sin occurs when federal judges overturn state policies on the basis of substantive federal values at some remove from a highly elaborated official text. That is, Lochner equals "discretionary power by federal judges." ner represents substantive due process. ${ }^{54}$ But substantive due process of one form or another has survived the universal condemnation of Lochner with great vitality. Indeed, many commentators have labeled the Court's commercial speech doctrine as Lochneresque, and that doctrine has produced many constitutional results identical to the statutory holdings that would follow from a capture theory of antitrust federalism. ${ }^{55}$ So I reject this meaning of Lochner. It does not isolate the thing that everyone condemns.

A different definition of Lochner's evil stresses its virtually irreversible constitutional condemnation of state law on the basis of highly debatable constitutional values. ${ }^{58}$ This feature was singular-and singularly bad-about Lochner. This feature is not present in a capture theory of antitrust federalism (or indeed in any theory of statutory construction).

Mr. Garland acknowledges my point, but dismisses it as technical detail. $^{\text {.7 I }}$ I disagree. Congressional power to govern is of more than mere technical significance. The ability of a federal majority to express its will makes the difference between oligarchy and democracy. This difference is plain from the Local Government Antitrust Act of $1984 .{ }^{58}$ That statute adjusts remedies available in municipal antitrust preemption litigation, and thus illustrates a point that should be obvious: Congress indeed can exercise its power to govern, in the antitrust field as elsewhere. More specifically, this antitrust law reaffirms the duty of federal courts to review the antitrust acceptability of municipal policy. ${ }^{88}$ Thus not only can Congress amend antitrust law; it has done so and has directed the judiciary to exercise federal supervision over local policy. That is democracy, not Lochner.

53. Garland, supra note 1, at 509.

54. Id. at 488 n.7 (quoting Nebbia v. New York, 291 U.S. 502 (1934)).

55. See Wiley, supra note 1 , at $779 \&$ nn.306-07.

56. This was Holmes' objection. See Lochner v. New York, 198 U.S. 45, 75 (1905) (Holmes, J., dissenting) ("[A] constitution is not intended to embody a particular economic theory.").

57. Garland, supra note $\mathbf{1}$, at $\mathbf{5 1 2}$ (congressional supremacy as "escape hatch").

58. Pub. L. No. 98-544, 98 Stat. 2750 (codified at 15 U.S.C.A. §§ 34-36 (West Supp. 1986)).

59. See Wiley, supra note 1 , at 777-78 n.299. 


\section{Conclusion}

Debates like this one have a known tendency to waterlog even the most buoyant reader. Nonetheless I have responded to Mr. Garland's main criticisms of my argument. Mr. Garland raises several issues, but a capture theory of antitrust federalism withstands his critique. 